\title{
Reducing enteric methane production from buffalo (Bubalus bubalis) by garlic oil supplementation in in vitro rumen fermentation system
}

\author{
Avijit Dey $^{1}$ [D $\cdot$ Shyam Sundar Paul ${ }^{1} \cdot$ Puran Chand Lailer ${ }^{1} \cdot$ Satbir Singh Dahiya ${ }^{1}$
}

Received: 27 August 2020 / Accepted: 20 January 2021 / Published online: 23 January 2021

(C) The Author(s) 2021 OPEN

\begin{abstract}
Enteric methane production contributes significantly to the greenhouse gas emission globally. Although, buffaloes are integral part of livestock production in Asian countries, contributing milk, meat and draft power, the contribution of enteric methane to environmental pollution attracts attention. The present study investigated the efficacy of garlic (Allium sativum) oil in reducing enteric methane production from buffaloes (Bubalus bubalis) by in vitro rumen fermentation. Garlic oil (GOL) was tested at four concentrations [0 (Control), $33.33 \mu \mathrm{l}$ (GOL-1), $83.33 \mu \mathrm{l}(\mathrm{GOL}-2)$ and $166.66 \mu \mathrm{l}$ (GOL-3) per litre of buffered rumen fluid] in $100-\mathrm{ml}$ graduated glass syringes and incubated at $39^{\circ} \mathrm{C}$ for $24 \mathrm{~h}$ for in vitro rumen fermentation study. Supplementation of GOL-1 increased $(p<0.05)$ total gas production in comparison with GOL-3; however, it remained comparable $(p>0.05)$ with control and GOL-2. Graded doses of garlic oil inclusions reduced $(p<0.001)$ methane concentration (\%) in total gas and total methane production $(\mathrm{ml} / \mathrm{g} \mathrm{DM})$, irrespective of concentrations. The feed degradability, volatile fatty acids and microbial biomass production (MBP) were not affected $(p>0.05)$ by GOL-1, but these tended to decrease in GOL-2 with marked reduction $(p<0.01)$ in GOL-3. The decrease $(p<0.01)$ in $\mathrm{NH}_{3}-\mathrm{N}$ concentration in fermentation fluid in the presence of garlic oil, irrespective of concentration, suggests reduced deamination by inhibiting rumen proteolytic bacterial population. The activities of ruminal fibrolytic enzymes (CMCase, xylanase, $\beta$-glucosidase, acetyl esterase) were not affected by lower dose (GOL-1) of garlic oil; however, reduction $(p<0.05)$ of these enzymes activity in rumen liquor was evident at higher doses (GOL-2 and GOL-3) of supplementation. This study shows positive impact of garlic oil supplementation at low dose $(33.33 \mu \mathrm{l} / \mathrm{l}$ of rumen fluid) in reducing enteric methane production, thereby, abatement of environmental pollution without affecting feed digestibility.
\end{abstract}

Keywords Gas production · Volatile fatty acids · Ruminal enzymes · Microbial protein · Environmental pollution

\section{Introduction}

Enteric methane production from domestic ruminants is one of the largest contributors of greenhouse gas (GHG) emission from agriculture sector. Asia is home for more than $90 \%$ of the world's buffalo population, contributing significantly to GHG emission. Ruminants loss a substantial amount of feed energy [1] due to methane production by the archaea present in rumen. In the diet of ruminants, a significant portion of proteins is solubilized very fast during mastication, resulting release of about $56-65 \%$ nitrogen in the rumen fluid, which is ultimately responsible for huge losses (25-35\%) of nitrogen through absorbed ammonia by rumen wall [2]. Therefore, improving feed utilization efficiency in ruminants not only accelerates animal production but also reduces environmental pollution. Supplementation of ionophore antibiotics and other chemicals have been beneficial in achieving these goals. But prohibition of their use by European Unions from 2006 due to development microbial resistance

Avijit Dey, avijitcirb@gmail.com | 'Division of Animal Nutrition and Feed Technology, ICAR—Central Institute for Research on Buffaloes, Hisar, Haryana 125 001, India. 
and presence of residues in animal products stimulated researchers for alternatives to increase animal production with concomitant lowered environmental pollution.

Globally, livestock contributed methane to the environment in the tune of $2720 \mathrm{Tg} \mathrm{CO}_{2}$-eq. per year in 2014 [3] from enteric feed fermentation and manure management. Livestock shares about $37 \%$ of the total anthropogenic methane emission and is major source of methane production in agriculture sector [4]. Within the agricultural sectors, methane emission from feed fermentation in the gut of livestock species contributes approximately $40 \%$ of total GHG, which has been estimated to increase by $11 \%$ from the period 2001-2011 [5]. With contribution of 13\% global livestock together with $57 \%$ of the world's buffalo and $16 \%$ cattle, India positions first in worldwide livestock population [6]. Ministry of Environment and Forests (MOEF), Govt. of India reported $9.8-54.40 \mathrm{~kg} / \mathrm{head} / \mathrm{year}$ of methane production equaling $205.8-1142.4 \mathrm{~kg} \mathrm{CO}_{2}$-eq. from buffaloes. Thus, there is an urgent need for reducing methane production by enteric methane mitigation from buffaloes while sustaining production performances.

In the last few years, considerable attention has been given to the plant secondary metabolites as potential feed additives to replace antibiotics and rumen fermentation modulators in animal feeds [7]. The composition of garlic oil (GOL) consists of molecules naturally found in the plant and compounds occurring during processing which mainly includes diallyl sulphide, allicin and allyl mercaptan [8]. It has been demonstrated that these compounds might impact rumen fermentation by affecting methanogens and protozoa population [9]. However, predominance of methanogenic species in the rumen and their association with protozoa could determine the inhibition of methanogenesis. Doses of garlic oil, like other secondary metabolites, are also crucial in achieving the desired effect as higher concentration could be inhibitory to fibrolytic microbes, resulting reduced feed digestibility. Therefore, the present investigation was undertaken to explore the in vitro efficacy of garlic (Allium sativum) oil supplementation on methanogenesis, rumen functions and gas production in buffaloes.

\section{Materials and methods}

The present experiment was carried out in the Division of Animal Nutrition and Feed Technology, ICAR-Central Institute for Research on Buffaloes (CIRB), Hisar, Haryana, India (29.1203_N, 75.8069_E). Strict compliances were followed with the recommendations of the National Animal Ethics Committee (New Delhi, India). The guidelines of the Institute Animal Ethics Committee of CIRB were continued with respect to rumen liquor collection and the care of the rumen fistulated animals.

\subsection{Experimental design and substrate}

The substrate for the study was prepared by grinding sorghum (Sorghum bicolor) hay in an electric grinder to form $1 \mathrm{~mm}$ particle size. Garlic oil (W250309) from SigmaAldrich $\mathrm{Ltd}$. was examined at four concentrations $(0,1.0 \mu \mathrm{l}$, $2.5 \mu \mathrm{l}$ and $5.0 \mu \mathrm{l}$ per $30 \mathrm{ml}$ of buffered rumen fluid) to get a concentration of GOL, 0 (Control), $33.33 \mu \mathrm{l}(\mathrm{GOL}-1), 83.33 \mu \mathrm{l}$ (GOL-2) and $166.66 \mu \mathrm{l}$ (GOL-3) per I of fermentation fluid. Three syringes per treatment per run with two incubation runs were accomplished to get representative results.

\subsection{Collection of rumen inoculum}

Four rumen-cannulated Murrah buffalo steers (avg. age 2.5 years, $380 \pm 14 \mathrm{~kg}$ B.W.) were used to collect rumen liquor before morning feeding. They were fed on wheat straw offered ad libitum and a limited amount of standard concentrate mixture (19\% CP and $72 \%$ TDN) and green oats in the morning to meet nutritional requirements [10]. The animals were housed in a good ventilated shed and fed individually. Fresh water was made available for drinking free of choice. Rumen inoculum was collected from both solid and liquid phase between 09:00 and 09:30 h according to standard procedures. Rumen liquor from each animal was mixed in equal volume and brought to the laboratory in a wormed thermos flask for further use. Rumen liquor was handled in laboratory under anaerobic conditions with constant flushing of $\mathrm{CO}_{2}$.

\subsection{In vitro incubation}

Garlic oil at four concentrations was added in fermentation fluid and investigated in a completely randomized design for this in vitro study. Accurately weighed ( $200 \mathrm{mg} \pm 5 \mathrm{mg}$ ) sorghum hay was mixed with $30 \mathrm{ml}$ of buffer mixed rumen fluid (2:1; buffer: rumen liquor) in glass syringes $(100 \mathrm{ml})$ marked with a scale of reading and incubated at $39^{\circ} \mathrm{C}$ for $24 \mathrm{~h}[11,12]$. Three syringes containing only buffered rumen fluid except substrate were incubated as blank. The syringes were gently shaken at 2-h interval by hand during the incubation period to avoid sticking of substrate and proper mixing of feeds with rumen inoculum.

\subsection{Total gas and methane estimation}

Gas production was recorded after $24 \mathrm{~h}$ of incubation from the upward movement of the piston from its initial position due to fermentation of substrate [13]. The total net gas production because of substrate fermentation was 
determined by deducting gas production in blank from the sample syringe. Methane estimation was done at $24 \mathrm{~h}$ of incubation by sampling $200 \mu \mathrm{l}$ gas from the upper space of the syringe in a Hamilton airtight syringe. The gas sample was then injected into NUCON-5700 (Nucon Engineers, New Delhi, India) gas chromatograph fitted with flame ionization detector (FID) and Porapak-Q packed SS column. Hydrogen used as carrier gas was kept at 69 kilopascal $(\mathrm{kPa})$ column pressure. The column injector, detector and oven temperature were $140{ }^{\circ} \mathrm{C}, 150^{\circ} \mathrm{C}$ and $60^{\circ} \mathrm{C}$, respectively. For comparison, a standard methane and carbon dioxide (1:1) mixture (Centurion Scientific, New Delhi) was used.

\subsection{Short-chain fatty acids estimation}

After 24-h incubation, supernatant $(1 \mathrm{ml})$ from individual syringe content was kept in a centrifuge tube and mixed with $0.20 \mathrm{ml}$ metaphosphoric acid $(25 \%, \mathrm{v} / \mathrm{v})$. The mixture was incubated for $2 \mathrm{~h}$ at room temperature, and supernatant was collected after centrifugation for $10 \mathrm{~min}$ at $5000 \mathrm{~g}$. Short-chain fatty acids were estimated by injecting $1 \mu \mathrm{l}$ supernatant into NUCON-5700 gas chromatograph fitted with flame ionization detector (FID) and chromosorb-101 glass column [14]. The column pressure for hydrogen and zero moisture air were $138 \mathrm{kPa}$ and $69 \mathrm{kPa}$, respectively. Temperatures of column oven, injector and detector were $170^{\circ} \mathrm{C}, 240^{\circ} \mathrm{C}$ and $250^{\circ} \mathrm{C}$, respectively.

\subsection{In vitro degradability of dry matter and microbial protein synthesis}

With repeated washings with neutral detergent solution (NDS) [15], the syringe content was transferred to 500-ml spout-less beakers. After refluxing the contents for $1 \mathrm{~h}$, the filtrate was collected in previously weighed crucibles (G1). Crucibles were then oven-dried at $105^{\circ} \mathrm{C}$ for $24 \mathrm{~h}$ to get constant weight for dry matter determination. In vitro dry matter degradability (TDDM) was estimated as follows.

\subsection{Analyses of ruminal enzymes}

After the end of 24-h incubation, the whole syringe content $(30 \mathrm{ml}$ ) was transferred to a $100-\mathrm{ml}$ conical flask and incubated for $3 \mathrm{~h}$ at $40^{\circ} \mathrm{C}$ after mixing with $5 \mathrm{ml}$ each of carbon tetrachloride and lysozyme solution $(0.1 \mathrm{M}, \mathrm{pH}$ 6.8). Then sonication was done at $4{ }^{\circ} \mathrm{C}$ for $6 \mathrm{~min}$ in ice bath and centrifuged at $17,000 \times \mathrm{g}$ for $20 \mathrm{~min}$ at $4{ }^{\circ} \mathrm{C}$. The supernatant was collected for the estimation of ruminal enzyme activities viz. carboxymethyl cellulase (CMCase), xylanase, acetyl esterase and $\beta$-glucosidase. The standards of glucose and xylose were used to estimate the reducing sugar released, by spectrophotometrically at $575 \mathrm{~nm}$ for quantification of CMCase and xylanase [16]. The acetyl esterase and $\beta$-glucosidase activities were measured as per the procedures of Huggins, Lapides [17] and Shewale, Sadana [18], respectively.

\subsection{Ammonia-nitrogen analysis}

Ammonia- $\mathrm{N}$ concentration in the fermentation fluid was analysed by micro-diffusion technique [19], where $1.0 \mathrm{ml}$ each of supernatant from syringe contents and $\mathrm{Na}_{2} \mathrm{CO}_{3}$ saturated solution was kept in reverse direction of outer chamber of Conway disc and $1.0 \mathrm{ml}$ of $2 \%$ boric acid solution with mixed indicators was kept in inner chamber. After proper greasing, the discs were capped. Mixing of the solutions of the outer chamber was done by keeping the discs on the palm of the hand with slowly moving and placed in an incubator at $39{ }^{\circ} \mathrm{C}$ for $3 \mathrm{~h}$. The boric acid in the inner chamber was titrated with $\mathrm{N} / 100 \mathrm{H}_{2} \mathrm{SO}_{4}$ to get $\mathrm{NH}_{3}-\mathrm{N}$ concentration. Three blanks were included for correction of $\mathrm{NH}_{3}-\mathrm{N}$ produced from the buffered rumen fluid [20].

\subsection{Chemical analysis and statistical examination}

Samples of sorghum hay and fermentation residue were analysed to determine DM by the oven-drying method (934.01) and organic matter by muffle furnace incineration

$\operatorname{TDDM}(\%)=\{$ (Dry weight of the substrate taken for incubation - weight of the residue $)$

$\div$ (Dry weight of the substrate) $\} \times 100$

The microbial biomass production (MBP) and partitioning factor (PF) was calculated [13]. PF was defined as the ratio of substrate in vitro truly degraded to gas volume produced by it.

$\mathrm{MBP}=$ Substrate truly degraded $-($ gas volume $\times 2.20 *)$

*2.20 is the stoichiometrical factor for roughage fermentation. method (967.05) of Association of Official Analytical Chemists [21]. Neutral detergent fibre (NDF) and acid detergent fibre (ADF) were determined by the method of Van Soest et al. [15].

The one-way analysis of variance (ANOVA) by SPSS version 17.0 software was performed, and the data were analysed as a completely randomized design, with garlic oil as fixed effect and incubation run as random effect. 
Differences among means were tested using Duncan's multiple range tests by Snedecor and Cochran (1994) and significance was declared when $p \leq 0.05$.

\section{Results and discussion}

The effects on rumen microbial fermentation by addition of essential oils depend on the types of essential oils, their active components and dose of inclusion besides other factors like dietary composition of the animals [22]. Various bioactive components present in garlic oils viz. diallyl sulphide, allicin and allyl marcaptan were reported to have direct antimicrobial property to a specific group of organisms [7]. In the present study (Fig. 1), comparable $(p>0.05)$ gas production was evident at lower doses of garlic oil supplementation (GOL-1 and GOL-2) with control (CON); however, reduced $(p<0.05)$ total gas production $(\mathrm{ml} / \mathrm{g} \mathrm{DM})$ was observed at higher dose (GOL-3) of supplementation. The methane concentration in the gas on percentage basis or absolute methane production was reduced $(p<0.001)$ with supplementation of graded levels of garlic oil (Fig. 2).

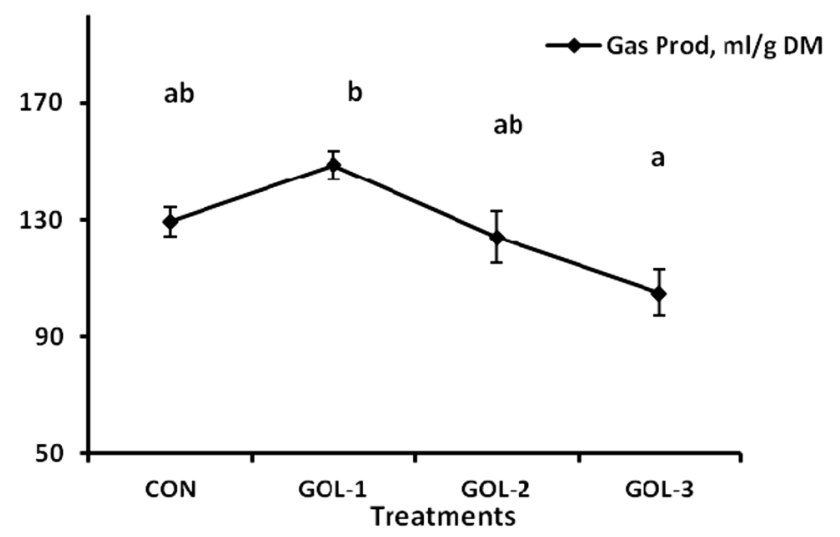

Fig. 1 Influence of graded doses of garlic oil on in vitro gas production

Fig. 2 Total methane production ( $\mathrm{ml} / \mathrm{g} \mathrm{DM})$ and its concentration (\%) in total gas as influenced by graded doses of garlic oil supplementation
Gas is produced in the rumen by fermentation of carbohydrate mainly by fibrolytic microbes. The methanogenic archaea form methane by capturing hydrogen and carbon dioxide of fermentation which emits into the environment by eructation. Many researchers $[7,23]$ reported direct inhibitory effects of organosulfur compounds present in the garlic oil on methanogenic archaea by inhibiting membrane lipid synthesis of the archaeal community. The decrease in total gas production at higher dose (GOL-3) of supplementation could be due to random inhibition of rumen microbial population [24]. The results are in consistent with earlier workers $[25,26]$, who also observed dose-dependent variations in gas production with either garlic oil (100-200 mg/kg DM) or garlic powder (64-128 g/ $\mathrm{kg}$ DM) supplementation.

In the current investigation, inclusion of garlic oil (GOL1) did not produce any effect on truly degradable $D M$, but it tended to decrease in GOL-2 with marked reduction $(p<0.01)$ in GOL-3 (Table 1). Similar to our study, Nanon et al. [25] observed linear increase in DM degradability up to doses of $400 \mathrm{mg} / \mathrm{kg}$ DM with linear decrease in DMD in $800 \mathrm{mg} / \mathrm{kg}$ onwards after incubation for 24 and $48 \mathrm{~h}$. A lowered degradability of DM and fibre was reported by Busquet et al. [7] on in vitro culture by addition of garlic oil (300 mg/l). The influence of garlic oil on variation in feed digestibility could be due to the proportion of different $S$ containing components present in the oil and the culture process. It is suggestive that rumen microbes could either adapt or degrade components present in garlic oil [27]. Modulation of microbial community and/or changes in individual microbial species determines the adaptation of rumen microbes on exposure to essential oils [28].

The microbial biomass production (MBP) because of fermentation followed the same trend $(p<0.05)$ of $\mathrm{DMD}$; however, partitioning factor (PF), an indication of efficiency of microbial protein production, remained similar, irrespective of doses of garlic oil. The relationship between gas production and microbial biomass production is inverse, particularly when expressed in per unit

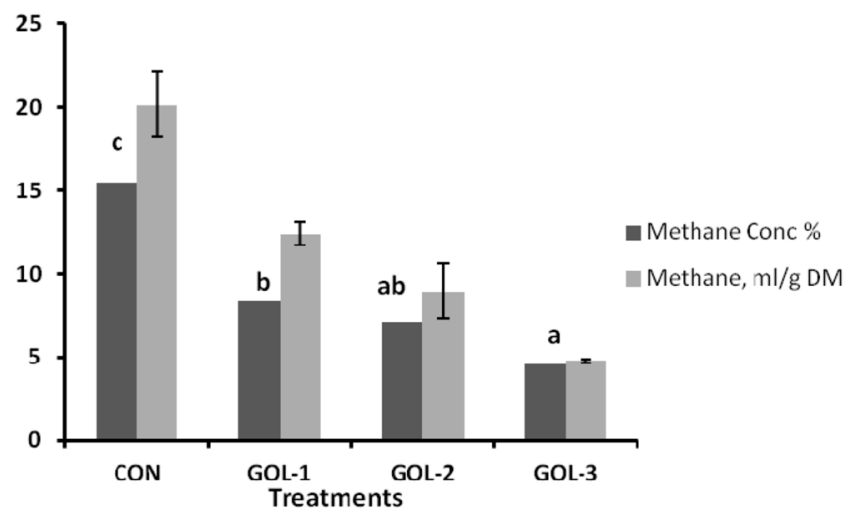


Table 1 Effect of garlic oil supplementation on in vitro feed degradability and microbial biomass production

\begin{tabular}{lcccrrrr}
\hline Attributes & \multicolumn{2}{c}{ Treatments } & & SEM & $p$ value \\
\cline { 2 - 5 } & \multicolumn{1}{c}{ CON } & GOL-1 & \multicolumn{1}{c}{ GOL-2 } & GOL-3 & & \\
\hline TDDM (\%) & $60.75^{\mathrm{b}}$ & $60.06^{\mathrm{b}}$ & $53.67^{\mathrm{ab}}$ & $45.43^{\mathrm{a}}$ & 3.68 & 0.007 \\
MBP (mg/g DM) & $322.96^{\mathrm{b}}$ & $273.44^{\mathrm{ab}}$ & $263.73^{\mathrm{ab}}$ & $223.67^{\mathrm{a}}$ & 22.49 & 0.024 \\
MBP (mg/100 mg DDM) & 53.13 & 45.40 & 49.21 & 49.27 & 2.05 & 0.131 \\
PF & 4.71 & 4.04 & 4.36 & 4.34 & 0.18 & 0.124 \\
\hline
\end{tabular}

TDDM truly degradable dry matter, $M B P$ microbial biomass production, $P F$ partitioning factor CON control, GOL-1, GOL-2 and GOL-3 are garlic oil (33.33, 83.33 and $166.66 \mu \mathrm{l} / \mathrm{l}$ buffered rumen fluid, respectively)

${ }^{a, b}$ Means with different superscripts within a row differ significantly $(p<0.05)$ of substrate truly degraded [29]. In the present study, although gas production was reduced at higher doses of garlic oil, the reduced degradability of substrate resulted lower in MBP.

Supplementation of garlic oil affected volatile fatty acid production in a dose-dependent manner (Table 2). The molar proportion of acetate remained similar in GOL-1; however, it was reduced $(p<0.01)$ in higher doses $(\mathrm{GOL}-2$ and GOL-3). A trend to increase propionate and butyrate, reduced $(p=0.001)$ acetate to propionate ratio was observed with GOL-1 and GOL-2 supplementation. However, adverse effects on these parameters were observed in GOL-3 treatment. The results are in confirmatory of Busquet et al. (2005), who also observed higher propionate with lower acetate and thereby reduced its ratio by addition of garlic oil ( $300 \mathrm{mg} / \mathrm{l})$ in both continuous and batch culture. The decrease in volatile fatty acids production in higher doses could be due to the toxic antimicrobial effect of garlic oil, which was also explained by reduction in DMD (Table 1).

The specific activities of CMCase and xylanase were comparable $(p>0.05)$ between CON and lower dose of garlic oil supplementation (GOL-1). However, a reduction in activities of both the enzymes was observed at higher doses (GOL-2 and GOL-3). Although $\beta$-glucosidase activity was reduced at higher doses of garlic oil, they remained comparable $(p>0.05)$ between GOL-2 and
GOL-3. Similar activities of $\beta$-glucosidase and acetyl esterase were reported in both control group and GOL-1 supplementation (Table 3 ), suggesting no inhibitory effects on these enzymes at lower dose (GOL-1).

The reduced activities of all these ruminal enzymes at higher doses (GOL-2. GOL-3) of garlic oil supplementation could be owing to inhibition of fibrolytic rumen microbes [30], which was also described by reduced feed degradability (Table 1). In a study with supplementation of garlic powder to cattle, Wanapat et al. [31] demonstrated decreased populations of ruminal protozoa and bacteria. While investigating effects of various essential oils on diversity of rumen microbial population, Patra and $\mathrm{Yu}$ [32] described inhibition of cellulolytic bacterial population on supplementation garlic oil.

Several plant bioactive compounds including the organosulfur compounds present in the garlic oil have the capability to reduce the deamination process by reducing proteolytic and hyper ammonia producing bacteria in the rumen [33]. In the present study, the $\mathrm{NH}_{3}-\mathrm{N}$ concentration was decreased $(p<0.05)$ in fermentation media, irrespective of dose. Cardozo et al. [34],35 also reported reduced ammonia-N concentration with the addition of garlic oil. However, Busquet et al. [7] observed no reduction in ammonia- $\mathrm{N}$ concentration by continuous or batch culture. The variation in findings could be explained by the type of garlic oil,
Table 2 Effect of garlic oil supplementation on in vitro ruminal volatile fatty acids production and ammonia- $\mathrm{N}$ concentration

\begin{tabular}{lcccccc}
\hline Attributes & \multicolumn{2}{l}{ Treatments } & & SEM & $p$ value \\
\cline { 2 - 6 } & CON & GOL-1 & GOL-2 & GOL-3 & & \\
\hline Acetate $(\mathrm{mM} / \mathrm{dl})$ & $3.49^{\mathrm{c}}$ & $3.41^{\mathrm{bc}}$ & $3.19^{\mathrm{ab}}$ & $3.05^{\mathrm{a}}$ & 0.10 & 0.002 \\
Propionate $(\mathrm{mM} / \mathrm{dl})$ & $0.89^{\mathrm{b}}$ & $0.96^{\mathrm{b}}$ & $0.88^{\mathrm{b}}$ & $0.79^{\mathrm{a}}$ & 0.04 & 0.002 \\
Butyrate $(\mathrm{mM} / \mathrm{dl})$ & $0.25^{\mathrm{a}}$ & $0.28^{\mathrm{b}}$ & $0.27^{\mathrm{ab}}$ & $0.26^{\mathrm{ab}}$ & 0.01 & 0.044 \\
$\mathrm{~A}: \mathrm{P}$ ratio & $3.92^{\mathrm{b}}$ & $3.55^{\mathrm{a}}$ & $3.64^{\mathrm{a}}$ & $3.88^{\mathrm{b}}$ & 1.09 & 0.001 \\
$\mathrm{NH}_{3}-\mathrm{N}(\mathrm{mg} / \mathrm{dl})$ & $16.51^{\mathrm{d}}$ & $14.23^{\mathrm{c}}$ & $12.66^{\mathrm{b}}$ & $10.37^{\mathrm{a}}$ & 0.62 & 0.001 \\
\hline
\end{tabular}

CON control, GOL-1, GOL-2 and GOL-3 are garlic oil $(33.33,83.33$ and $166.66 \mu \mathrm{l} / \mathrm{l}$ buffered rumen fluid, respectively)

$a, b, c$ Means with different superscripts within a row differ significantly $(p<0.05)$ 
Table 3 Changes in ruminal enzyme activities ( $\mathrm{mlU} / \mathrm{mg}$ protein) on in vitro incubation of sorghum hay with graded doses of garlic oil

\begin{tabular}{lllllll}
\hline Attributes & \multicolumn{3}{l}{ Treatments } & & SEM & $p$ value \\
\cline { 2 - 5 } & CON & GOL-1 & GOL-2 & GOL-3 & & \\
\hline CMCase & $419.32^{\mathrm{c}}$ & $409.13^{\mathrm{bc}}$ & $387.24^{\mathrm{b}}$ & $298.66^{\mathrm{a}}$ & 2.51 & $<0.001$ \\
Xylanase & $734.33^{\mathrm{c}}$ & $712.86^{\mathrm{c}}$ & $652.49^{\mathrm{b}}$ & $557.3^{\mathrm{a}}$ & 6.72 & $<0.001$ \\
-Glucosidase & $623.43^{\mathrm{b}}$ & $609.26^{\mathrm{b}}$ & $496.22^{\mathrm{a}}$ & $478.26^{\mathrm{a}}$ & 7.94 & $<0.001$ \\
Acetyl esterase & $164.27^{\mathrm{b}}$ & $141.13^{\mathrm{ab}}$ & $139.21^{\mathrm{ab}}$ & $122.65^{\mathrm{a}}$ & 3.86 & $<0.001$ \\
\hline
\end{tabular}

CON control, GOL-1, GOL-2 and GOL-3 are garlic oil $(33.33,83.33$ and $166.66 \mu \mathrm{l} / \mathrm{l}$ buffered rumen fluid, respectively)

a,b,c Means with different superscripts within a row differ significantly $(p<0.05)$ substrate used for fermentation and rumen microorganisms involved in fermentation process.

\section{Conclusions}

Garlic oil has the potential to modulate rumen microbial fermentation for reducing methane and ammonia-nitrogen production. However, decrease in feed digestibility at higher doses of garlic oil supplementation was evident. Supplementation of garlic oil @ $33.33 \mu \mathrm{l} / \mathrm{I}$ of rumen fluid revealed reduction (38.35\%) in enteric methane production without impeding feed digestion. As degradation and/or adaptation of active compounds of garlic oil like other plant secondary metabolites could occur in the rumen, an in vivo study for long duration should be conducted before using garlic oil as feed additive for improving animal performance and reducing methane emission.

Acknowledgements The authors sincerely acknowledge the financial assistance and necessary facilities made by the Indian Council of Agricultural Research (ICAR) and Director, Central Institute for Research on Buffaloes (CIRB) for conducting this study.

\section{Compliance with ethical standards}

Conflict of interest The authors declared that they have no conflict of interest.

Open Access This article is licensed under a Creative Commons Attribution 4.0 International License, which permits use, sharing, adaptation, distribution and reproduction in any medium or format, as long as you give appropriate credit to the original author(s) and the source, provide a link to the Creative Commons licence, and indicate if changes were made. The images or other third party material in this article are included in the article's Creative Commons licence, unless indicated otherwise in a credit line to the material. If material is not included in the article's Creative Commons licence and your intended use is not permitted by statutory regulation or exceeds the permitted use, you will need to obtain permission directly from the copyright holder. To view a copy of this licence, visit http://creativecommons .org/licenses/by/4.0/.

\section{References}

1. Johnson KA, Johnson DE (1995) Methane emissions from cattle. J Anim Sci 73(8):2483-2492

2. Min B, Barry T, Attwood G, McNabb W (2003) The effect of condensed tannins on the nutrition and health of ruminants fed fresh temperate forages: a review. Anim Feed Sci Technol 106(1):3-19

3. Dangal SR, Tian H, Zhang B, Pan S, Lu C, Yang J (2017) Methane emission from global livestock sector during 1890-2014: magnitude, trends and spatiotemporal patterns. Glob Change Biol 23(10):4147-4161

4. Steinfeld H, Gerber P, Wassenaar T, Castel V, Rosales M, De Haan C, LSL S (2006) Environmental issues and options. Food and Agriculture Organization, Rome

5. Tubiello F, Salvatore M, Cóndor Golec R, Ferrara A, Rossi S, Biancalani R, Federici S, Jacobs H, Flammini A (2014) Agriculture, forestry and other land use emissions by sources and removals by sinks. Statistics Division Food and Agriculture Organization, Rome

6. FAO (2017) FAO statistical databases. Food and Agriculture Organization of the United Nations, Rome

7. Busquet M, Calsamiglia S, Ferret A, Carro M, Kamel C (2005) Effect of garlic oil and four of its compounds on rumen microbial fermentation. J Dairy Sci 88(12):4393-4404

8. Lawson LD (2006) The composition and chemistry of garlic cloves and processed garlic. In: Koch HP, Lawson LD (eds) Garlic: the science and therapeutic application of Allium sativum L. and related species. Williams and Wilkins, Baltimore

9. Chaves A, Stanford K, Dugan M, Gibson L, McAllister T, Van Herk F, Benchaar C (2008) Effects of cinnamaldehyde, garlic and juniper berry essential oils on rumen fermentation, blood metabolites, growth performance, and carcass characteristics of growing lambs. Livestock Sci 117(2):215-224

10. Paul SS, Lal D (2010) Nutrient requirements of buffaloes. Satish Serial Publishing House, Delhi

11. Menke K, Raab L, Salewski A, Steingass H, Fritz D, Schneider W (1979) The estimation of the digestibility and metabolizable energy content of ruminant feedingstuffs from the gas production when they are incubated with rumen liquor in vitro. J Agric Sci 93(01):217-222

12. Menke KH, Steingass $H$ (1988) Estimation of the energetic feed value obtained from chemical analysis and in vitro gas production using rumen fluid. Anim Res Dev 28(1):7-55

13. Blümmel M, Makkar H, Becker K (1997) In vitro gas production: a technique revisited. J Anim Physiol Anim Nutr 77(1-5):24-34

14. Cottyn BG, Boucque CV (1968) Rapid method for the gas-chromatographic determination of volatile fatty acids in rumen fluid. J Agric Food Chem 16(1):105-107 
15. Pv VS, Robertson J, Lewis B (1991) Methods for dietary fiber, neutral detergent fiber, and nonstarch polysaccharides in relation to animal nutrition. J Dairy Sci 74(10):3583-3597

16. Miller GL (1959) Use of dinitrosalicylic acid reagent for determination of reducing sugar. Anal Chem 31(3):426-428

17. Huggins C, Lapides J (1947) Chromogenic substrates IV. Acyl esters of $p$-nitrophenol as substrates for the colorimetric determination of esterase. J Biol Chem 170(2):467-482

18. Shewale J, Sadana J (1978) Cellulase and $\beta$-glucosidase production by a basidiomycete species. Can J Microbiol 24(10):1204-1216

19. Conway E (1962) Ammonia. General method microdiffusion analysis and volumetric error. Crosby Lockwood and Son Ltd, London, pp 98-100

20. Singh RK, Dey A, Paul SS, Singh M, Dahiya SS, Punia BS (2019) Associative effects of plant secondary metabolites in modulating in vitro methanogenesis, volatile fatty acids production and fermentation of feed in buffalo (Bubalus bubalis). Agrofor Syst. https://doi.org/10.1007/s10457-019-00395-3

21. AOAC (1995) Official methods of analysis, 16th edn. Association of Official Analytical Chemists, Washington

22. Cardozo P, Calsamiglia S, Ferret A, Kamel C (2005) Screening for the effects of natural plant extracts at different $\mathrm{pH}$ on in vitro rumen microbial fermentation of a high-concentrate diet for beef cattle. J Anim Sci 83(11):2572-2579

23. De Rosa M, Gambacorta A, Gliozzi A (1986) Structure, biosynthesis, and physicochemical properties of archaebacterial lipids. Microbiol Rev 50(1):70

24. Mbiriri D, Cho S, Mamvura C, Choi N (2015) Assessment of rumen microbial adaptation to garlic oil, carvacrol and thymol using the consecutive batch culture system. JVet Sci Anim Husb 4:1-7

25. Nanon A, Suksombat W, WenZhu Y (2015) Use of essential oils for manipulation of rumen microbial fermentation using batch culture. The Thai J Vet Med 45(2):167

26. Sahli F, Darej C, Moujahed N (2018) Potential of white garlic powder (Allium sativum L.) to modify in vitro ruminal fermentation. S Afr J Anim Sci 48(2):253-260

27. Hart K, Yanez-Ruiz D, Duval S, McEwan N, Newbold C (2008) Plant extracts to manipulate rumen fermentation. Anim Feed Sci Technol 147(1):8-35
28. Benchaar C, Calsamiglia S, Chaves A, Fraser G, Colombatto D, McAllister T, Beauchemin K (2008) A review of plant-derived essential oils in ruminant nutrition and production. Anim Feed Sci Technol 145(1):209-228

29. Blümmel $M$, Steinga $\beta H$, Becker $K$ (1997) The relationship between in vitro gas production, in vitro microbial biomass yield and $\mathrm{N}$ incorporation and its implications for the prediction of voluntary feed intake of roughages. Br J Nutr 77(06):911-921

30. Zhu Z, Mao S, Zhu W (2012) Effects of ruminal infusion of garlic oil on fermentation dynamics, fatty acid profile and abundance of bacteria involved in biohydrogenation in rumen of goats. Asian-Austral J Anim Sci 25(7):962

31. Wanapat $M$, Khejornsart $P$, Pakdee P, Wanapat S (2008) Effect of supplementation of garlic powder on rumen ecology and digestibility of nutrients in ruminants. J Sci Food Agric 88(13):2231-2237

32. Patra AK, Yu Z (2012) Effects of essential oils on methane production and fermentation by, and abundance and diversity of, rumen microbial populations. Appl Environ Microbiol 78(12):4271-4280

33. Wallace RJ, McEwan NR, McIntosh FM, Teferedegne B, Newbold CJ (2002) Natural products as manipulators of rumen fermentation. Asian Austral J Anim Sci 15(10):1458-1468

34. Cardozo P, Calsamiglia S, Ferret A, Kamel C (2004) Effects of natural plant extracts on ruminal protein degradation and fermentation profiles in continuous culture. J Anim Sci 82(11):3230-3236

35. Mbiriri DTCS, Mamvura Cl, Choi NJ (2016) Assessment of rumen microbial adaptation to garlic oil, carvacrol and thymol using the consecutive batch culture system. J Vet Sci Anim Husb $4(1): 1-7$

Publisher's Note Springer Nature remains neutral with regard to jurisdictional claims in published maps and institutional affiliations. 